\title{
Empowering Sex Workers in Guatemala: Establishing a Sustainable Nonprofit (with Students) in a Developing Country
}

Jodi Finkel, Loyola Marymount University

ABSTRACT In 2005, with two of my students, I started a literacy program in a red-light district in Guatemala City. In 2007, we became a nonprofit organization dedicated to the promotion of the rights of sex workers in Guatemala (i.e., Women for Justice, Education, and Awareness, known in Spanish as MuJER). Today, MuJER provides literacy classes and accelerated elementary school, vocational training, antiviolence programs, and grassroots organizing. We have worked with hundreds of women, both at our Community Empowerment Center and "door-to-door" in red-light districts. Using the experience of MuJER, this article provides recommendations for professors interested in working with students to create a nonprofit in the developing world: select students whose skill sets are different than your own; start by creating a program (not by formally establishing a 501(c) (3) tax-exempt organization); and recognize that the nonprofit's long-term sustainability requires commitment to grant writing for years to come.

\section{T}

n 2005, two undergraduate students, Ana Moraga and Tania Torres, and I started a literacy program for prostitutes at La Linea, a notoriously dangerous red-light district in an impoverished area of Guatemala City. Two years later, our literacy program became a nonprofit organization dedicated to the promotion of the rights of female sex workers in Guatemala. Our organization, known in Spanish as MuJER (Mujeres por la Justicia, Educacion, y el Reconocimiento, or Women for Justice, Education, and Awareness), is founded on the belief that all women, regardless of employment, have a right to self-worth, education, economic opportunity, and a life free from violence. Today, nine years since we began, we have worked with hundreds of women in multiple red-light districts in Guatemala's capital. We offer literacy classes, accelerated elementary school, and a range of vocational programs. More important, through our "door-to-door" visits in red-light districts, our classes and workshops, and our grassroots organizing, we help sex workers to find a sense of personal dignity, to know their rights, and to have a voice in the community. In 2009, MuJER opened its first Community Empowerment Center and, in April 2013, we moved into a larger space that accommodates additional classrooms and more capacity for women at workshops.

Jodi Finkel is an associate professor of political science at Loyola Marymount University who researches judiciaries and human rights in Latin America. She is a founder of MuJER (www.mujerguatemala.org) and president of Por un Mejor Hoy (www.hoycommunityonline.net), an alternative college-break program in Mexico and the United States. She can be reachedatjinkel@lmu.edu.
In December 2012, we celebrated our first high school graduate, who crossed the stage in her cap and gown to receive her diploma.

Our journey from a small literacy program at the La Linea redlight district to a grassroots organization empowering hundreds of sex workers has not been easy. More than once, I feared we would be forced to close down as we ran low on funding. Yet, since we began in 2005, we have continued to increase the number of women that we work with and to expand our services and programs. Over the years, I have been asked by other professors how to start a sustainable nonprofit with students. Ultimately, I think MuJER's long-term success is primarily due to the resilience, dedication, and complementary skill sets of the two students, Ana and Tania, who laid the foundation for the establishment of an organization that could later be run by an all-Guatemalan staff. The other crucial element for success is a professor's long-term commitment to grant writing-a commitment that will continue long after the students have returned home.

HOW MUJER BEGAN: NATIONAL PUBLIC RADIO, ONE WOMAN'S STORY, AND A LITERACY PROGRAM (LEER ES PODER, OR READING IS POWER)

In January 2005, while driving in my car, I heard a story on National Public Radio (NPR) about a group of prostitutes (I now use the term sex workers, which is preferred by the women) at La Linea. About four city blocks long, La Linea is situated in downtown Guatemala City on the site of an abandoned railroad line. The women's cramped workrooms run along both sides of the tracks. Of the several women interviewed for the NPR story, Susi, 
a 41-year-old woman and the mother of seven children, stated that she wanted to learn to read. For days afterward, her words danced in the back of my mind. How could Susi create a better life for herself and for her children if she could not read? What could I do about it?

When I was in graduate school, I volunteered as a literacy tutor with adults at the public library. As a result of that experience, I knew that teaching someone to read would require an extended time commitment. In 2005, when I heard the NPR story, I was still
Within days of their arrival in Guatemala City, these two intrepid young women began visiting $L a$ Linea. Two weeks later, they called me to say that they had met Susi! However, neither Susi nor any of the other women they met were interested in learning to read. Instead, they viewed Ana and Tania with skepticism; the women of La Linea doubted that they would stay long enough to teach anyone to read. Ana and Tania quickly realized that the goal of creating a literacy program at La Linea would prove to be much more difficult than the three of us had originally imagined.

\section{Ana and Tania did not give up. Instead, on their own initiative, they developed a strategy of "trust building." Day after day, Ana and Tania visited La Linea, doing small acts of assistance.}

an untenured political science professor and, although I conducted research in Latin America, the idea of moving to Guatemala seemed out of the question. However, as a university professor, I realized that I had a powerful force on my side: a cohort of engaged young people who are ready to change the world. Thus, I began to consider students who might be audacious enough to spend a year in Guatemala.

I immediately thought of Ana Moraga. By then a graduating senior, Ana had been my student in her freshman year. She was born in Guatemala, had come to the United States when she was 12 years old, and was fluent in Spanish. More important than her country of origin or her language skills, I knew that Ana was a young woman who possessed a deeply held passion for women's rights and was a leader in our campus's social-justice community. So, in late January 2005, I asked her to drop by my office. When she came in early February, I played the NPR story for her and then asked, "Ana, if I give you \$30o, will you move to Guatemala, go to La Linea, find Susi, and teach her to read?" She agreed, and our literacy program, Reading is Power (Leer es Poder), was born.

The next day, I received a phone call from Ana's roommate, Tania Torres. Tania had introduced herself to me when she was organizing a day-long community forum about violence against women in Juarez, Mexico. The forum included presentations by representatives from nongovernmental organizations (NGOs), government officials, the families of victims, and victim-support groups. From this experience, I knew that Tania was both a dedicated activist and a first-rate organizer. Thus, when she called to ask is she could move to Guatemala with Ana, I knew we had our team.

During the next few months, the three of us began our preparations. I was on the board of a local nonprofit and arranged to have it serve as our fiscal sponsor. Having an officially recognized NGO act as our fiscal sponsor meant that all donations to our literacy program were fully tax deductible. As for Ana and Tania, their preparations included arrangements to volunteer in Guatemala City with a French antipoverty NGO (i.e., International All Together for Dignity Fourth World). In exchange for volunteering 20 hours each week, Ana and Tania would receive free room and board, which was important because neither of them would draw a salary for their work with the literacy program. We began hosting small fundraisers to pay for their travel, and the dean of the College of Liberal Arts and our university's Jesuit Society each gave \$1,ooo, which helped to cover Ana's and Tania's other expenses (e.g., bus fare and cellular phones). After graduating in May 2005, Ana and Tania moved to Guatemala in August. ${ }^{2}$
Whereas others might have thrown in the towel, Ana and Tania did not give up. Instead, on their own initiative, they developed a strategy of "trust building." Day after day, Ana and Tania visited La Linea, doing small acts of assistance. In addition to these visits, they contacted Guatemala's national literacy program (i.e., Comité Nacional de Alfabetización [CONALFA]), which trained Ana and Tania as government-certified literacy instructors.

Slowly, as personal relationships between Ana and Tania and the women of our community developed, we began to know more about them. At any one time, about 250 women are working at $L a$ Linea. They range in age from 18 to 65 but most are older than 35 . The women are mired in poverty and most survive day-to-day. About half of the women are Guatemalan; the others are migrants from neighboring Central American countries. Most speak Spanish, rather than an indigenous language, as their first language. Many are single mothers, and they often have several children. Some of the women of La Linea never received any education; others were forced to leave school at an early age. Almost all of the women we work with have been victims of sexual abuse and violence. Some of the women were trafficked (i.e., sold into prostitution), a form of modern-day slavery. The price for sex can be as little as \$2.5o. Each woman has a story, and the stories are often heartbreaking.

After continuing to visit La Linea for two months, Ana and Tania's strategy paid off in October 2005: Vilma asked to be taught to read and became our first student! Gradually, other women also asked to be taught to read. The classes were free, taught by one-on-one instruction, and took place in the women's workrooms at La Linea.

In the course of the following year (2006), Ana and Tania realized that a one-year literacy program would not be enough to make a significant difference in the lives of the women at $L a$ Linea. They determined that what was needed was an organization dedicated to empowering sex workers at La Linea, and this was the spark for MUJER. MuJER's mission would be to provide sex workers with a belief in their own self-worth, to enable individual women to have life choices, and to allow the sex-worker community to have a voice in society. To dedicate their full efforts to MuJER, Ana and Tania left the French NGO and arranged to live in an unfurnished house that belonged to Ana's family and that we could use as the MuJER office. By then, we had been awarded a $\$ 13$,ooo grant from Mama Cash, a foundation in the Netherlands, and could pay both Ana and Tania a small salary. A few months after embarking on MuJER, Ana and Tania called to tell me that Susi had asked to learn to read! 
MUJER: FOUNDING AN NGO, EXPANDING OUR SERVICES AND ESTABLISHING A COMMUNITY CENTER

In February 2007, at about the same time that I heard the wonderful news about Susi, Tania began the paperwork to establish MuJER as a US tax-exempt, or "501c3," organization (from the section of the US Internal Revenue Code that regulates nonprofit organizations). Becoming an official 501c3 not only represented our new vision,
By early 2009, we finally felt confident enough in our funding for Ana to begin searching for a location for our Community Empowerment Center. In February, we began renting space in a colonial house in downtown Guatemala City and opened our doors. For many women of La Linea-and, over time, for sex workers from other redlight districts in Guatemala City-our Community Empowerment Center serves as a home away from home.

\section{For many women of La Linea-and, over time, for sex workers from other red- light districts in Guatemala City-our Community Empowerment Center serves as a home away from home.}

it also allowed us to establish a bank account in MuJER's name, thereby enabling us to receive all donations directly. It also gave us more credibility when we applied to major foundations for large grants. In September 2007, we received official notification of our 501c3 status. At this same time, Ana and Tania hired the daughter of a sex worker as MuJER's receptionist, which deepened our positive standing in the sex-worker community.

With the establishment of our office and with the additional time that Ana and Tania could now dedicate to our work, the type of programs we offered began to expand. In addition to literacy classes, the women asked for both an accelerated elementary-school program (another CONALFA program), which is required for some vocational programs, and computer classes, which we taught with donated laptops.

Some of our new services reflected the women's input; in other cases, the new programs reflected the needs that Ana and Tania observed in the community. In particular, they began to develop antiviolence programming. Sex workers suffer violence at the hands of clients, local gang members, police, and domestic partners. In Guatemala, these acts occur with impunity; the larger society views the women of our community as not deserving of protection. Thus, Ana and Tania began to host interactive antiviolence workshops in one of the women's workrooms at La Linea. Furthermore, MuJER became a member of Guatemala's Network Against Violence (Red No a la Violencia), an umbrella organization that unites associations that work to end violence against women in Guatemala. We also began to organize the women of La Linea to participate in Guatemala's Annual Day of No Violence Against Women protest march on November 25.

With MuJER moving forward, Ana and Tania developed the next goal for MuJER: creating a Community Empowerment Center. The women's workrooms were not conducive to teaching and it was not safe to conduct large workshops at La Linea. However, the main challenge was a lack of long-term funding because we were still operating on a very limited budget. Through Ana and Tania's personal connections with foundations, and through my grant writing, we obtained enough funding to maintain our services, but we could not yet commit to the extra costs that a community center would entail. ${ }^{3}$

In July 2007, Tania returned to the United States to pursue a master's degree in nonprofit management, and Ana remained in Guatemala as MuJER's sole executive director. I met Susi at about the same time. It was after her literacy class, in which she had just learned the letter "Q," a wonderful experience for both of us. Tania became a member of MuJER's board of directors, and I began to work more closely with Ana.

\section{A STABLE SPACE: EXPANDING PROGRAMMING AT OUR COMMUNITY EMPOWERMENT CENTER}

Even after we opened our Community Empowerment Center and sex workers were now coming to us, we continue to conduct door-to-door visits at La Linea. These visits allow us to maintain personal relationships with the women, meet new arrivals at $L a$ Linea, and invite women to take advantage of the programs at our Center.

The Community Empowerment Center also enabled us to expand the types of vocational programs and workshops we offered. We began to provide scholarships for vocational training to women from our community, and we then hired these women to teach classes at the Center. Although our in-house vocational programs provide women with supplemental income-and, in a few cases, enabled them to leave sex work and pursue microenterprises-the most important aspect of the programs is that they bring women into our Center. We then can enroll them in literacy classes and in elementary school or invite them to join a workshop or community activity. At the Center, we also can focus more deeply on our antiviolence campaign. Workshops that were previously conducted at La Linea are now held at our Center and we can offer them more frequently.

In the summer of 2010, five and a half years after I first heard the NPR story, I received a phone call from Susi in Guatemala. By then, she was completing fourth grade in our accelerated elementary school program. Susi was excited to tell me that she had passed the reading and writing test at a vocational school and therefore had been admitted to the school's sewing and tailoring program.

\section{MAKING THE TRANSITION TO AN ALL-GUATEMALAN STAFF}

In the fall of 2010, after four years in Guatemala, Ana decided it was time to return to the United States. We hired Flor de Maria Pena, who was previously employed in the anti-trafficking division of the Guatemalan government, as our new executive director. We currently have a four-member, all-Guatemalan staff; two of those employees are from the sex-worker community. In addition to our paid staff, MuJER continues to benefit from a cohort of dedicated volunteers and long-term international interns.

Under Flor's leadership, MuJER's programs have continued to evolve and expand. Our door-to-door personal visits at La Linea have been transformed into "traveling workshops," in which we educate women about a specific topic (e.g., self-esteem, antiviolence, trafficking, and reproductive rights) for an entire month. On any given Tuesday (i.e., the day that we visit La Linea), we speak with 90 to 100 women. At the end of the month, we host a final workshop on the topic, followed by a lunch for all of the participants (which often 
are catered by women from the community). Today, our workshops are frequently attended by 50 or more women.

Regarding MuJER's antiviolence campaign, Flor introduced a new program in which we accompany women through the process of filing violence complaints. In addition, MuJER continues to organize the women of La Linea to participate in the annual November 25 and March 8 antiviolence demonstrations in the capital. MuJER also has enabled sex workers to join the committee that organizes the November anti-violence demonstration, at which the women now carry a MuJER banner and wear MuJER t-shirts. In 2013 more than 50 women also marched with us in the March 8 protest.

Every January and July, before our semester-long programs begin, we visit different red-light districts to invite women to enroll in our classes at our Community Empowerment Center. Last January, we invited sex workers from nine different red-light districts in Guatemala City. This year, our classes were overflowing4 and our both the federal and state levels. 5 It is possible to pay a lawyer, CPA, or business service to do the paperwork, but this can cost several thousand dollars (in addition to the filing fees). Furthermore, once your organization is established as a qualified nonprofit, you will need to file annual tax returns. As a nonprofit, you do not pay taxes, but you must file taxes (i.e., to provide a record of your funding and expenditures) with both the federal and state governments.

Thus, rather than immediately establishing a 501c3, it is better to create a program and then seek an existing $501 \mathrm{c}_{3}$ organization to serve as your program's fiscal sponsor. The sponsor accepts taxdeductible donations on your behalf and your program benefits by receiving 501c3 status without the fees, paperwork, or tax responsibilities. To find a sponsor, identify nonprofits that share the general goals of your program. In the case of MuJER, I was on the board of the Democracy Council, a local nonprofit, and I knew that the Council wanted to increase its presence in Latin

\section{To find a sponsor, identify nonprofits that share the general goals of your program. In the case of MUJER, I was on the board of the Democracy Council, a local nonprofit, and I knew that the Council wanted to increase its presence in Latin America.}

workshops were standing-room-only. Thus, to accommodate our growing population of daily visitors, in April 2013 we moved into a larger building, only a few blocks from our original location. Our goals for 2014 include creating a sex-worker leadership council, providing mental-health services at our Center, working with the daughters of sex workers, and establishing ourselves as a legal entity in Guatemala.

\section{STARTING AN NGO IN THE DEVELOPING WORLD: A HOW-TO GUIDE BASED ON MUJER}

In this section, I lay out advice for professors who seek to work with their students to address a particular issue in another country.

\section{Begin by Creating a Program (under a Fiscal Sponsor), Not a 501c3}

As professors with specific expertise in global issues, it makes sense that we begin to consider concrete ways to help people in the developing world whose stories pull at our heartstrings. Although it may seem necessary to formally establish a 501c3, doing so initially would be a mistake. Instead, determine if an existing group or nonprofit is already serving the individuals or the community you want to help and volunteer with it. For example, host fundraisers; write grants; recruit student interns; or provide technical, legal, or financial expertise.

That said, you might discover that no other existing organization is serving the community in the way that you want to assist. At that point, it is time to think about creating a program. Given the costs-for both fees and paperwork-associated with establishing a formal nonprofit organization, it does not make sense to establish a 501c3 before you have a viable program on the ground.

As for the costs, the current application fee for filing for federal tax-exempt status is either $\$ 400$ or $\$ 850$, depending on an organization's projected income in the next three years. In addition to paying this fee to the federal government, there is a small incorporation fee in the state where you will be headquartered. Becoming a tax-exempt organization also requires preparing the application paperwork at
America. The Democracy Council listed our project on its website and agreed to process donations for our literacy program and to wire the money to Guatemala.

It is crucial when working with a fiscal sponsor to establish mechanisms that account for all donations. For example, if a donor did not personally notify me, it was difficult to track donations that were sent directly to the Democracy Council. This limited my ability to send a timely acknowledgment to the donor, to establish a donor list, and to guarantee that all donations were actually sent to our account in Guatemala. Furthermore, because we had not set up a schedule for wiring funds to Guatemala and because the Council was understaffed, we often did not receive deposits on a regular basis. I advise establishing a formal agreement with the fiscal sponsor that includes bi-monthly notification of all donations and a structured funds-wiring plan (i.e., every two or three months).

When your program has established a track record of success, it makes sense to then become a recognized nonprofit. Finally, when you have become a 501c3 designation, I advise that you watch out for tricksters. Multiple times a year, I receive letters that claim to be from a government "Business Compliance Division" and state that MuJER must file additional paperwork including a check for $\$ 150$ to $\$ 250$. These letters are scams. To maintain the good standing of your organization, always check on your state's Office of the Secretary of State website to determine which annual filings and fees are required.

\section{Commit to Grant Writing}

As professors, we have experience in grant writing; therefore, it is likely that the grant writing task will be our responsibility. The bottom line for sustaining a nonprofit is to keep the money coming in. I worked with student writers but it proved more efficient to write the grants myself and grant writing remains one of my primary tasks for MuJER. If you are dedicated to the survival of your nonprofit, be prepared to commit to writing grants for many years to come. 


\section{Develop a Board of Directors}

To establish a 501c3, you are required to establish a minimum three-member board of directors. At MuJER, we found it useful to list the duties of each position and to assign these posts based on members' skill sets and the amount of time they were willing to commit. Our board's main responsibilities include oversight of our executive director and fundraising. As president of the board, I ensure that members are fulfilling their duties and I maintain regular contact with our team in Guatemala. Board members visit Guatemala once a year, on a rotating schedule, and we also conduct meetings with our executive director via Skype.

Regarding membership, my advice is to keep the board of directors small. Many people may ask to join, but every individual is one more person to coordinate for meetings and approvals. Instead, invite people who have a specific skill set and are willing to fundraise or donate a specific amount of money. We also have found it useful to include a native speaker on the board to ensure that there is no confusion in our written documentation. us, but now we accept only those candidates who can commit for six months. This makes it worth our executive director's time to train them and also gives the interns time to build relationships with the women of MuJER.

\section{Find the Right Students}

Finally, the most important advice I can offer for creating a sustainable nonprofit is to choose the right students. I believe that if I had started MuJER with any two students other than Ana and Tania, MuJER would not be in existence today. Although both women had done well academically, performance in the classroom was not what was required. They had proven organizational abilities and interpersonal communications skills, and these qualities were enhanced by resilience and dedication. Furthermore, they were willing to stay in Guatemala for more than one year; when they left, the organization was stable and productive. The final important ingredient was that their skill set did not mimic my own; instead, we were complements to one another: they had the

\section{The final important ingredient was that their skill set did not mimic my own; instead, we were complements to one another: they had the people skills and organizational talents, and I was the grant writer and administrator back home.}

\section{Transition from Students to a Professional Staff}

As MuJER progressed from being run by Ana-a student and a friend-to being run by an executive director who we did not know personally, the board's oversight function became more important, and we realized that we needed to run our organization more professionally. With Ana, we did not write a job description, sign a contract (her salary was set by verbal agreement), or conduct an annual performance evaluation. When she requested funds, we wired the money without reviewing any budgets or expenditures. When we hired Flor, we realized that we needed to establish oversight mechanisms. We created a job description and now sign an annual contract with our executive director. We introduced a system of quarterly reporting, as well as an annual report, and we now conduct an end-of-the-year performance review. On receipt of the quarterly report, we wire funds for the next three months of operation.

\section{In-Country Interns}

MuJER's international interns, who have come from the United States, Canada, and the United Kingdom, have proven invaluable. ${ }^{6}$ They teach classes, go door-to-door with us in red-light districts, represent MuJER's positions at conferences, and bring new ideas. They also have helped with grant applications, web design, and development of our social media. Our interns are unpaid (we help them find jobs teaching English part-time), volunteer at least 20 hours a week, and commit for six months.

Over time, Ihave changed the intern-hiring process. I now conduct all interviews in Spanish (many applicants do not have the language skills that they claim to have). I also require that applicants have previous experience living in the developing world. Furthermore, many interns want to spend only two or three months with people skills and organizational talents, and I was the grant writer and administrator back home.

Together we created not only a nonprofit organization but also a community that is changing lives. Alondra, who started with us in the fourth grade, graduated from culinary arts school. Paola and Sharon, both MuJER scholarship students, are in their third year of high school. Elizabeth is employed by the Guatemalan government to develop antiviolence neighborhood associations. Rubi is working as a nurse. Susi, our initial inspiration, finished sixth grade with us. For some, our success is measured by these types of concrete accomplishments. However, for me, MuJER's greatest success is when a woman says to me, "I have rights, I have dignity, and I deserve respect." =

\section{NOTES}

1. Catherine Elton, “Guatemala City's Prostitute Soccer Team,” January 12, 2005, on Day to Day.

2. Ana holds both US and Guatemalan passports; neither she nor Tania had any type of student or work visa; and Tania entered Guatemala as a tourist.

3. Much of our early funding came from two foundations in the Netherlands: Mama Cash and Cordaid.

4. For example, in 2014, we have 15 women in basic literacy classes and 31 women enrolled in grades 1-6. In addition, of the women who completed sixth grade through our program, six are now in junior high, five are in high school, one more has graduated high school, three are in math tutorials (required for nursing school), and one is applying to university (where she wants to study law and women's rights).

5. At the federal level, this includes creating by-laws, articles of incorporation, and obtaining an Employment Identification Number. At the state level, you must first file to become a business entity and then submit additional materials to establish yourself as a nonprofit organization.

6. Our interns find MuJER via our website and on Internet sites (e.g., idealist. org and volunteerguatemala.org) that place volunteers with nonprofits in the developing world. 